Article

\title{
Do Economists Punish Less?
}

\author{
Jonas Pilgaard Kaiser, Kasper Selmar Pedersen and Alexander K. Koch * (D) \\ Department of Economics and Business Economics, Aarhus University, Aarhus V 8210, Denmark; \\ jonas-kaiser@hotmail.com (J.P.K.); pedersen_ka@hotmail.com (K.S.P.) \\ * Correspondence: akoch@econ.au.dk; Tel.: +45-87-16-55-39
}

Received: 28 August 2018; Accepted: 28 September 2018; Published: 30 September 2018

\begin{abstract}
A number of studies discuss whether and how economists differ from other disciplines in the amount that they contribute to public goods. We view this debate as incomplete because it neglects the willingness to sanction non-cooperative behavior, which is crucial for maintaining social order and for sustaining the provision of public goods. We study the decision whether to engage in costly punishment of a free rider in a survey-based experiment with 1423 students from seven study areas in the social sciences, as well as medicine at Aarhus University, Denmark. Using a dictator game and a social dilemma game, that captures essential features of the public goods game, we replicate previous findings that economics students give significantly less than students from other disciplines. However, when subjects decide whether or not to punish a free rider, we find that economics students are just as likely to punish as students from other disciplines.
\end{abstract}

Keywords: social preferences; punishment; public goods game; dictator game; norm compliance; experimental economics; economists

\section{Introduction}

The willingness to sanction non-cooperative behavior is crucial for maintaining social order and for ensuring access to essential public goods. Examples are numerous and include the provision of public health, environmental protection, corruption, tax compliance, and collective actions like strikes and teamwork. The fact that an agent can benefit from a public good even without having contributed to it creates a tension between individual and collective rationality, which according to standard economic theory will lead to undersupply of public goods if agents have self-interested preferences [1]. Moreover, a large body of experimental work reveals that public goods provision may not be sustained solely by some individuals having preferences for (conditional) cooperation [2]. To ensure high levels of public goods provision it is, therefore, critical to have a mechanism for punishing free riders (for a recent survey see [3]).

The success of a society thus relies on (i) the right institutional design and (ii) cooperation and the presence of members who are willing to sanction defectors even at personal cost. Economics as a discipline clearly can contribute to (i). Indeed, economists occupy many important positions in public and private administration that allow them to take or influence societally-relevant decisions. Yet, exposing people to economic ideas may harm (ii) if it makes people less likely to cooperate or reluctant to punish defectors.

Since Marwell and Ames [4] published their findings on the selfish behavior of economists in public goods experiments, it has been widely debated whether economists behave differently than people from other disciplines. A growing body of evidence suggests that economics students tend to behave more selfishly than other students (see Section 2) and that even brief instruction on economic rationality can shift behavior in that direction (e.g., [5]).

A subtheme of the debate is whether the observed differences between study areas arise because of self-selection or socialization, i.e., whether they arise prior to or during university. A wide range 
of studies find that self-selection is the main reason for the behavioral differences across academic majors in ultimatum games [6], in principal-agent games on corruption [7], and in empirical behavior regarding contributions to social funds [8,9]. Conversely, multiple studies show an effect of lectures that highlight the ideas of self-interest, rationality, and utility-maximization; including effects on trustworthiness [10], voting behavior [11], and attitudes towards greed [12]. Wang et al. [12] find that the effect of taking economics courses is only present during the first three economics courses-with no significant marginal effect of taking further economics courses thereafter. This is in line with Bauman and Rose [9], who find that microeconomics instructions affect the contributions to social funds for non-economists but not for economists.

Thus far, the debate has centered on social preferences as captured in games such as dictator, ultimatum, or public goods games (see Section 2). Here, behavior can be explained by fairness theories based on equity considerations, yet punishment behavior cannot be fully explained by inequity averse preferences, and retaliation seems to be an important motive, too (e.g., [13]). Punishment can be seen as a (second-level) public good [14,15]. However, empirical studies show that people view punishment decisions differently from contribution decisions, and that in the latter, people emphasize different principles depending on whether there is punishment or not [16]. Thus, it is a critical question whether economists are less willing to punish defectors than non-economists-a question which to our knowledge has not been addressed yet.

To fill this gap, we investigate both other-regarding and punishment behavior using a survey-based experiment with 1423 students from seven study areas in the social sciences as well as medicine at Aarhus University, Denmark. Using a dictator game and a social dilemma game, that captures essential features of the public goods game, we find that economics students give significantly less than students from other study areas. However, when subjects decide whether or not to engage in costly punishment of a free rider, we find that economics students do not punish less than students from other study areas.

\section{Related Literature}

Most studies on contributions and prosocial behavior of economists find that economists behave less prosocially than non-economists. For instance, economics training has been found to correlate with lower donations in dictator games [12,17], and economists defect more often in prisoners' dilemma games [10]. In public goods games, economists have been found to contribute less both when zero contributions constitute the Nash equilibrium [4] and when the introduction of a threshold establishes Nash equilibria with positive contributions [18]. Regarding public goods games, however, the literature is inconclusive: a meta-analysis by Zelmer [19] finds no significant influence of economics training on subjects' contributions. There are ambiguous findings also in ultimatum games. Carter and Irons [6] find that economists propose less to the responder than others, whereas Kagel et al. [20] find no difference between economics and psychology students. Taking the lab to the field, Yezer et al. [21] conduct a "lost-letter" experiment. In classrooms where economists or others are to attend a class, they leave envelopes (with stamp and address) that contain money. They find that economists are actually more likely to return the envelope than non-economists, thus acting more prosocially. Our contribution to the literature is that we are, to the best of our knowledge, the first to compare punishment behavior between economics students and students from other disciplines.

Typically, studies treat people with other academic backgrounds than economics as a homogenous group $[4,6-9,12,21]$ or they compare economists with a limited comparison group; e.g., nurses [18] or astronomers [10]. Our study additionally contributes to the literature by providing a discipline level comparison of prosocial behavior of economics students with students in several social sciences and medicine. 


\section{Method ${ }^{1}$}

\subsection{Overview}

To achieve a high number of participants from diverse fields of studies, we recruited participants during the breaks of large lectures in different disciplines and designed the study so that it could be completed online within 5-10 min. For this reason, the games had to be simple to explain, and the elicited strategies could not be too complex. Further, because subjects participated at different time points, decisions could not be made interactively.

The first goal of our paper is to investigate whether, like four decades ago in Marwell and Ames [4], there are differences in prosocial behavior between economics students (who are following today's more nuanced economics curriculum) and students from other disciplines. Therefore, we first elicited such behavior in a dictator game and a social dilemma game. The second goal of our paper is to examine whether differences similar to those in prosocial behavior can also be found in a punishment framework. Thus, in a third game, subjects were presented with a hypothetical punishment decision, in which they chose whether or not to punish a free rider, who violated a norm of contributing. Instructions were given one task at a time. Before each task, subjects answered control questions which provide us with a measure of their understanding of the task. Incentives were given through a random lottery procedure. At the end of the experiment, we drew for each of the first two tasks 20 subjects (with replacement; i.e., a subject could be chosen for both tasks), randomly matched them (see below), and paid them according to their decisions by bank transfer.

In sum, each subject participated in three tasks in the following order:

1. A dictator game with role uncertainty;

2. A social dilemma game; and

3. A hypothetical social dilemma game with punishment opportunity.

At the end of the experiment, subjects answered several survey questions about gender, age, study program, prior knowledge of the dictator game, and generalized trust ${ }^{2}$.

\subsection{Dictator Game}

The first task was a dictator game with role uncertainty. Each subject made a decision in the role of the dictator and divided an endowment of 100 DKK (approx. \$16 USD) between himself and an anonymous partner. This decision would be implemented in case the subject was one of the 10 subjects chosen to be a dictator. Each dictator was matched with one of the 10 recipients drawn from the entire pool of subjects in the study. We interpret giving in the dictator game as an expression of social preferences such as altruism and inequity aversion (e.g., [18] $)^{3}$.

\subsection{Social Dilemma Game}

For the second task, we implemented a multiplayer dictator game with an efficiency factor to establish a social dilemma. The game included essential features of the public goods game while being simpler to explain and implementable in a non-interactive survey setting. ${ }^{4}$ Each subject was part of

1 See Supplementary D for experimental instructions.

2 We used the World Values Survey question: "Generally speaking, do you think most people can be trusted, or do you think that you cannot be too careful in dealing with other people?" (Most people can be trusted, You cannot be too careful, Don't know/Don't want to answer)

3 To ensure that there was no framing effect from the way the control question was phrased, we ran two treatments. In one variant (altruistic treatment), the example in the control question had the dictator giving $90 \mathrm{DKK}$, and in the other variant (egoistic treatment) the dictator only gave $10 \mathrm{DKK}$. We found no differences across the two treatments (analysis available upon request) and, henceforth, pool the data from the dictator game.

4 Past multiplayer dictator games typically implement choices over discrete outcomes (see [22] for a survey and [23] for a recent example). Our game is also related to the Helping Game [24], where the dictator can "help" at a smaller cost than the benefit is to the recipient (the efficiency factor), and to the Patron Game [25], where only a single group member decides how 
a group of four, where each member had an endowment of 100 DKK. Every group member chose how much of his endowment to keep for himself. The rest of his endowment was multiplied by three and split equally among the other three, anonymous group members. That is, like in the standard public goods game, all group members made a contribution decision. Contributions were multiplied by an efficiency factor of three that ensured that there was a greater collective return to the money transferred to the other group members than to keeping it for oneself. Even though a group member did not receive anything back from his own contribution, the game captures the essence of the trade-off in the public goods game. In both settings, it is socially optimal for each group member to contribute his entire endowment, but the income-maximizing strategy is to keep the entire endowment. Subjects made their choices independently without feedback about the others' contributions. Twenty subjects were drawn from the entire subject pool, randomly matched into groups of four, and paid according to their decisions.

\subsection{Social Dilemma Game with Punishment}

The third task added a punishment option to the social dilemma game. Our interest is in punishment aimed at non-cooperators as these punishments are central to sustaining high levels of cooperation. ${ }^{5}$ Each subject was given a hypothetical scenario in which three group members gave their entire endowment to the others, and the fourth group member kept everything for himself. The scenario thus reflected the most extreme deviation from the norm of contributing, and we believed that the scenario would be most likely to trigger punishment. As such, it would provide an upper bound on subjects' inclination to punish free riders. The subjects were asked whether they would give up 10 DKK to reduce the earnings of the free rider by 100 DKK. Subjects were told that they were the only person with the opportunity to punish, in order to rule out free riding on costly punishment by others. We randomized subjects into two treatments. In both treatments, a subject was presented with a scenario where he had contributed the full endowment to the others in his own group. In the own group treatment, the subject had the choice whether or not to punish the free rider in his own group. In the other group treatment, the subject was not himself part of the group where the free riding occurred, but he could choose whether or not to punish the free rider in that other group. Social preferences, such as inequity aversion, can motivate punishment in both treatments. Differences in punishment behavior between the own group and the other group treatments may reflect negative reciprocity [26], which should only play a role in the own group treatment.

Given the aim of our study to recruit a large number of students from many different disciplines and the constraint that choices had to be elicited without real-time interactions, we opted for a straightforward hypothetical punishment decision. The alternative of playing out the social dilemma game with a punishment phase would have required using the so-called strategy method [27] to elicit punishment decisions for all the possible contribution vectors in the group. A drawback of our approach is that we rely on hypothetical stakes [28]. However, hypothetical stakes have been used in the literature with no change in the results. For instance, when comparing real with hypothetical payoffs, Gillis and Hettler [29] find no difference in behavior in a public goods game, and they find no effect on costly rejection in the ultimatum game, where the second-mover can reduce the first mover's earnings by rejecting the offer. Similar to our setting, Fehr and Gächter [14] use hypothetical outcomes in a public goods game to elicit whether subjects experience anger when they observe free riding. Relatedly, Kocher et al. [30] find no effect of varying stake size on punishment behavior in the public goods game. More generally, studies comparing behavior under hypothetical versus real stakes

much of his endowment to contribute to a public good that all group members benefit from. The essential difference, which also makes our setting closely resemble a public goods game, is that all players made a contribution decision.

5 The literature also documents punishment behavior by defectors aimed at cooperators (e.g., [13]). 
suggest that monetary rewards often reduce data variability with no effect on the average behavior (e.g., [31]).

\subsection{Participants}

A total of 1423 students from the fields economics, business administration, marketing and management communication, public policy, political science, law, psychology, and medicine at Aarhus University participated. Subjects were recruited through a short presentation in 17 large undergraduate lectures that students typically would take in their 2 nd or 4 th semester. The link to the survey was also posted on the course web pages. The data were collected 5-19 March 2018, using the online survey software Qualtrics (Provo, UT, USA). Through the random lottery procedure, subjects could earn up to 500 DKK (approx. 78 USD) - up to 100 DKK in the first task and up to 400 DKK in the second task. Average earnings among the 40 subjects drawn for payment were 131 DKK. The participation rate was $36.6 \%$ (calculated based on total enrollment in the different courses). ${ }^{6}$

\section{Hypotheses}

Many researchers have tried to explain how economics might influence individuals' actions; including the use of mathematical methods [32], the emphasis on rationality and income-maximization [12], and the norm of self-interest [33]. Following this line of thought, economics training could make people behave more selfishly and instill a belief that others behave selfishly as well. Yet, economics training also emphasizes the importance of designing the right kinds of institutions to support favorable outcomes from a social perspective. Moreover, modern economics curricula incorporate insights from behavioral and experimental economics; even undergraduate microeconomics textbooks typically include a discussion of the evidence for people having other-regarding preferences and of how this changes some of the predictions of traditional economic theory. Thus, the impact of modern economics teaching may be different today than it was decades ago. Our first aim, hence, is to test whether economics students act less prosocially than students from other disciplines:

Hypothesis 1 (H1): Economics students give more to others in the dictator game and the social dilemma game than students in other disciplines.

As mentioned, there is no direct evidence on subject differences in punishment behavior. Marwell and Ames [4] find that economists have a relatively more favorable view on selfish behavior, and Carter and Irons [6] find that economists tend to accept lower amounts as second-movers in the ultimatum game. Moreover, the economic line of thought stresses that it is irrational to punish other players in one-shot interactions because punishment is costly and entails no economic gains [26]. Hence, we reach our second hypothesis:

Hypothesis 2 (H2): The willingness to punish free riders is lower among economics students than among students in other disciplines.

\section{Results}

A total of 1423 subjects finished the survey. Our main sample contains the 1371 observations for which all variables and covariates are available.

6 This number is a lower bound on the participation rate as the number of students actually present in the lectures where the study was presented can be expected to be quite a bit lower than the number of students enrolled in the course (see also Supplementary B). 
To investigate whether economists behave differently from other disciplines, we operate both with a narrow definition that includes only students enrolled in the core economics undergraduate program at Aarhus University, 144 observations ( $10.5 \%$ of the main sample), and with a broad definition that includes also students in other programs with a heavy focus on economics in the curriculum (business administration, public policy, and marketing and management communication), 570 observations (41.6\% of the main sample). See Supplementary A, Table A1 for summary statistics. Section 5.1 summarizes the results from the dictator and the social dilemma games. Section 5.2 presents the results from the social dilemma game with punishment opportunity.

\subsection{Differences in Prosocial Behavior: Students in Economics versus Other Disciplines}

In line with Hypothesis H1, economists (broad definition in parentheses) give less on average than students in the other disciplines: 26.69 (33.73) versus 39.40 (41.15) DKK in the dictator game and 43.92 (55.02) versus 62.20 (64.03) DKK in the social dilemma game, respectively. Further, Mann-Whitney-Wilcoxon tests indicate that the amounts given to others by non-economists stochastically dominate those by economists (all with $p<0.001$ ). Giving in the dictator game (DG) and the social dilemma game (SDG) is correlated $(\rho=0.33, p<0.001)$. These results continue to hold when adding controls in regressions. Findings are qualitatively robust to estimating Tobit models (available upon request).

For the DG, Table 1 shows that adding controls does not much affect the economist-other disciplines gap in giving: The gap is not explained by differences in gender composition (males tend to give less) or confusion (prior knowledge of the DG and correctly answering the control question for the DG do not significantly affect giving). The difference in giving between economics students and others appears to increase with the number of semesters enrolled (specification 3 ), but the slope coefficients for the two groups are not significantly different $(F(1,1355)=0.40, p=0.52)$. Note that the interpretation of the economics dummy in that specification is different from the other specifications because part of the economist-other disciplines gap is captured through the semester interactions. These results continue to hold with the broad definition of economics, albeit with a smaller economist-other disciplines gap in giving. The final two specifications in Table 1 reveal that giving is higher in all other disciplines compared to economics, with medicine and psychology ranking highest.

A similar pattern emerges when considering just the event of zero amounts given in the DG. $41.9 \%$ of economists ( $26.1 \%$ with the broad definition) give nothing, compared to $15.1 \%$ (11.9\%) among the other disciplines. A logistic regression with controls added predicts that an economics student is $21.2 \%(10.6 \%)$ more likely to be a zero contributor (both marginal effects have $p<0.001$ ). 
Table 1. Ordinary least squares regressions for giving in the dictator game (DG).

\begin{tabular}{|c|c|c|c|c|c|c|c|c|}
\hline Variable & (1) & (2) & (3) & (4) & (5) & (6) & (7) & (8) \\
\hline Economics (narrow) & $\begin{array}{c}-12.53^{* * *} \\
(2.29)\end{array}$ & $\begin{array}{c}-11.05^{* * *} \\
(2.38)\end{array}$ & $\begin{array}{l}-6.56 \\
(7.39)\end{array}$ & & & & $\begin{array}{l}\text { Reference } \\
\text { category }\end{array}$ & $\begin{array}{l}\text { Reference } \\
\text { category }\end{array}$ \\
\hline Economics (broad) ${ }^{a}$ & & & & $\begin{array}{c}-7.33^{* * *} \\
(1.22)\end{array}$ & $\begin{array}{c}-5.88^{* * *} \\
(1.34)\end{array}$ & $\begin{array}{l}-2.58 \\
(3.39)\end{array}$ & & \\
\hline Business Administration & & & & & & & $\begin{array}{c}9.36^{* * *} \\
(2.54)\end{array}$ & $\begin{array}{c}9.26^{* * *} \\
(2.60)\end{array}$ \\
\hline Public Policy & & & & & & & $\begin{array}{c}11.23^{* *} \\
(4.58)\end{array}$ & $\begin{array}{c}12.05^{* *} \\
(4.82)\end{array}$ \\
\hline Marketing and Management Communication & & & & & & & $\begin{array}{l}8.46^{* *} \\
(3.34)\end{array}$ & $\begin{array}{c}7.10^{* *} \\
(3.43)\end{array}$ \\
\hline Other discipline & & & Referen & category & & & & \\
\hline Psychology & & & & & & & $\begin{array}{c}18.57^{* * *} \\
(2.50)\end{array}$ & $\begin{array}{c}17.24^{* * *} \\
(2.80)\end{array}$ \\
\hline Law & & & & & & & $\begin{array}{c}11.64^{* * *} \\
(2.62)\end{array}$ & $\begin{array}{c}9.59 * * * \\
(2.77)\end{array}$ \\
\hline Political Science & & & & & & & $\begin{array}{c}12.16^{* * *} \\
(2.66)\end{array}$ & $\begin{array}{c}11.60^{* * *} \\
(2.74)\end{array}$ \\
\hline Medicine & & & & & & & $\begin{array}{c}17.47^{* * *} \\
(2.81)\end{array}$ & $\begin{array}{c}15.82 * * * \\
(2.94)\end{array}$ \\
\hline Other subject & & & & & & & $\begin{array}{c}14.71 * * * \\
(3.18)\end{array}$ & $\begin{array}{c}13.27^{* * * *} \\
(3.47)\end{array}$ \\
\hline Male & & $\begin{array}{c}-4.93^{* * *} \\
(1.22)\end{array}$ & $\begin{array}{c}-4.93^{* * *} \\
(1.22)\end{array}$ & & $\begin{array}{c}-4.56^{* * *} \\
(1.28)\end{array}$ & $\begin{array}{c}-4.58^{* * *} \\
(1.28)\end{array}$ & & $\begin{array}{c}-3.67^{* * *} \\
(1.30)\end{array}$ \\
\hline Knows the DG & & $\begin{array}{l}-0.41 \\
(1.42)\end{array}$ & $\begin{array}{l}-0.38 \\
(1.42)\end{array}$ & & $\begin{array}{l}-0.37 \\
(1.41)\end{array}$ & $\begin{array}{l}-0.21 \\
(1.41)\end{array}$ & & $\begin{array}{l}-1.95 \\
(1.57)\end{array}$ \\
\hline DG control question correct & & $\begin{array}{l}-9.62 \\
(6.90)\end{array}$ & $\begin{array}{l}-9.60 \\
(6.88)\end{array}$ & & $\begin{array}{l}-8.81 \\
(6.79)\end{array}$ & $\begin{array}{l}-8.86 \\
(6.78)\end{array}$ & & $\begin{array}{c}-10.38 \\
(7.02)\end{array}$ \\
\hline Semester & & $\begin{array}{c}0.45 \\
(0.52)\end{array}$ & & & $\begin{array}{c}0.19 \\
(0.52)\end{array}$ & & & $\begin{array}{c}0.35 \\
(0.56)\end{array}$ \\
\hline
\end{tabular}


Table 1. Cont.

\begin{tabular}{|c|c|c|c|c|c|c|c|c|}
\hline Variable & (1) & (2) & (3) & (4) & (5) & (6) & (7) & (8) \\
\hline Semester $\times$ Economics ${ }^{b}$ & & & $\begin{array}{l}-0.87 \\
(2.20)\end{array}$ & & & $\begin{array}{l}-0.52 \\
(0.94)\end{array}$ & & \\
\hline Semester $\times(\text { Other discipline })^{b}$ & & & $\begin{array}{c}0.56 \\
(0.52)\end{array}$ & & & $\begin{array}{c}0.57 \\
(0.57)\end{array}$ & & \\
\hline Constant & $\begin{array}{l}39.44^{* * *} \\
(0.60)\end{array}$ & $\begin{array}{l}15.60 \\
(9.84)\end{array}$ & $\begin{array}{l}14.27 \\
(9.61)\end{array}$ & $\begin{array}{l}41.23^{* * *} \\
(0.71)\end{array}$ & $\begin{array}{l}13.16 \\
(8.37)\end{array}$ & $\begin{array}{l}10.96 \\
(8.60)\end{array}$ & $\begin{array}{l}26.91^{* * *} \\
(2.21)\end{array}$ & $\begin{array}{c}2.03 \\
(11.26)\end{array}$ \\
\hline Age dummies & No & Yes & Yes & No & Yes & Yes & No & Yes \\
\hline$R^{2}$ & 0.03 & 0.05 & 0.05 & 0.03 & 0.05 & 0.05 & 0.05 & 0.07 \\
\hline Number of observations & 1423 & 1371 & 1371 & 1423 & 1371 & 1371 & 1423 & 1371 \\
\hline
\end{tabular}

Public Policy, and Marketing and Management Communication. ${ }^{b}$ Adjusted for narrow/broad definition of Economics. 
The regressions for giving in the SDG in Table 2 reveal a similar picture. Here, confusion can explain part of the economist-other disciplines gap in contributions and more trusting individuals contribute more. The latter is in line with conditional cooperation driven by people with reciprocal preferences who respond to anticipated contributions by others. Compared to other disciplines, economics students are 12 percentage points less likely to believe that most people can be trusted, and being male reduces the probability of high trust by six percentage points (see Supplementary A, Table A2).

To investigate the trust channel in more detail, we focus just on economics, business administration, and law, which all have a similar share of 'high trust' subjects (those who believe that most people can be trusted; $56.8 \%, 56.2 \%$, and $59.9 \%$, respectively, compared to $82.9 \%$ for the other disciplines, see Supplementary A, Table A1). Comparing contributions among subjects who have 'high trust' in these study areas still reveals an economist-other disciplines gap in contributions: Economists contribute less than law $(F(1,703)=9.13, p=0.003)$ and business administration students $(F(1,703)=3.48, p=0.06)$ even when adding controls to the regression. The same holds for 'low trust' subjects. Again, economists contribute less than law $(F(1,703)=6.65, p=0.01)$ and business administration students $(F(1,703)=13.53, p<0.001)$.

As for the DG, results continue to hold with the broad definition of economics, albeit with a smaller economist-other disciplines gap. The final two specifications in Table 2 reveal that compared to economics giving is higher in all other disciplines (except public policy students who share lectures with economists), with medicine and psychology again ranking highest.

A similar picture emerges when considering just the event of zero contributions in the SDG: $35.8 \%$ of economists (21.8\% with the broad definition) give nothing, compared to $14.0 \%(12.3 \%)$ among the other disciplines. A logistic regression with controls added predicts that an economics student is 16.6 (6.1) percentage points more likely to be a zero contributor (marginal effects with $p<0.001$ and $p=0.004$, respectively).

Result 1. Economics students give less to others in the dictator game and the social dilemma game than students in other disciplines. This finding also holds when considering a broad definition of economics that includes students in other programs with a heavy focus on economics in the curriculum. 
Table 2. Ordinary least squares regressions for contributions to others in the social dilemma game (SDG).

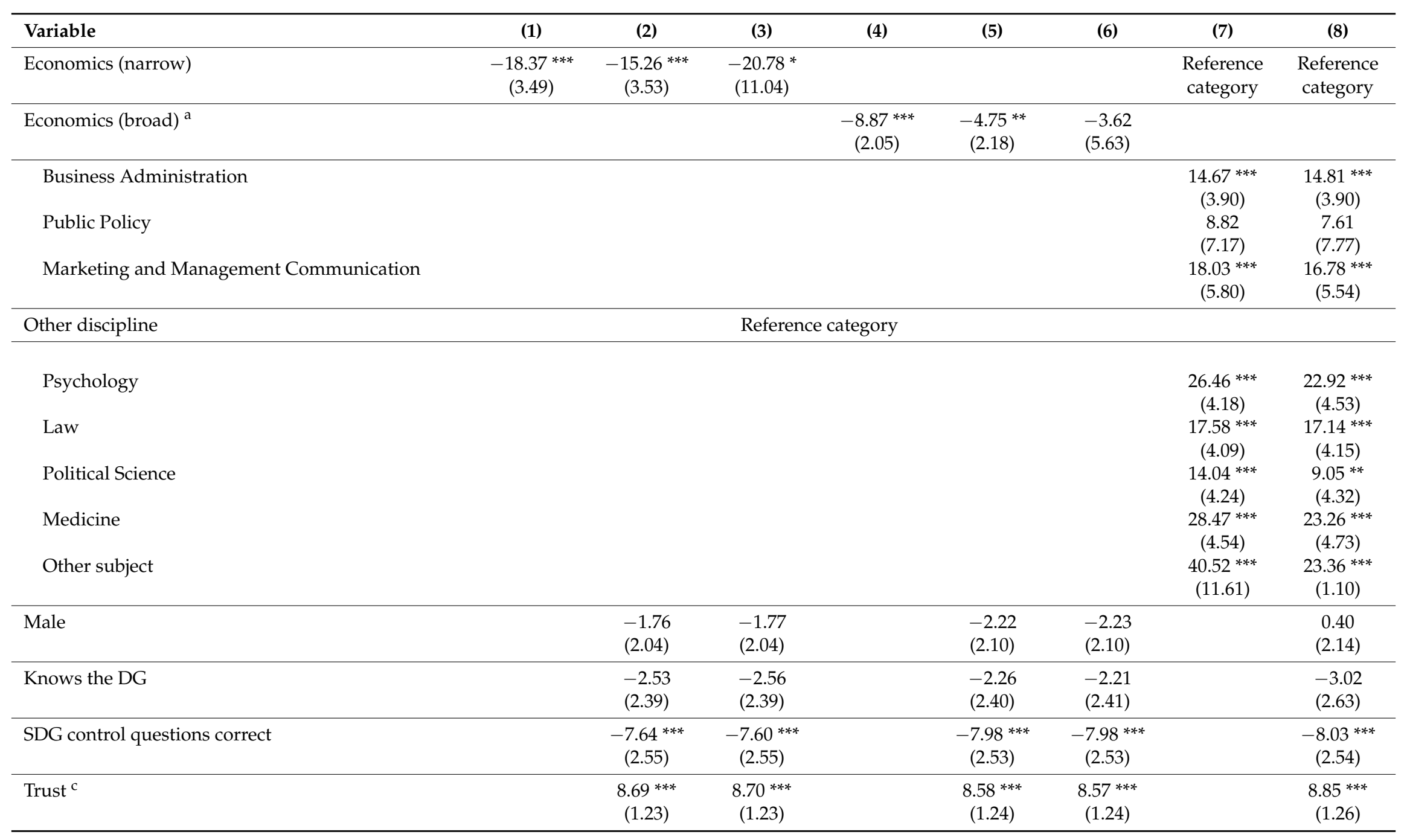


Table 2. Cont.

\begin{tabular}{|c|c|c|c|c|c|c|c|c|}
\hline Variable & (1) & (2) & (3) & (4) & (5) & (6) & (7) & (8) \\
\hline Semester & & $\begin{array}{l}2.11^{* *} \\
(0.88)\end{array}$ & & & $\begin{array}{l}1.81 * * \\
(0.88)\end{array}$ & & & $\begin{array}{c}2.53^{* * * *} \\
(0.94)\end{array}$ \\
\hline Semester $\times$ Economics ${ }^{b}$ & & & $\begin{array}{c}3.73 \\
(3.18)\end{array}$ & & & $\begin{array}{c}1.56 \\
(1.48)\end{array}$ & & \\
\hline Semester $\times(\text { Other discipline })^{b}$ & & & $\begin{array}{l}1.98^{* *} \\
(0.90)\end{array}$ & & & $\begin{array}{l}1.94 * \\
(1.02)\end{array}$ & & \\
\hline Constant & $\begin{array}{c}62.05^{* * *} \\
(1.04)\end{array}$ & $\begin{array}{c}7.16 \\
(16.25)\end{array}$ & $\begin{array}{c}8.76 \\
(16.96)\end{array}$ & $\begin{array}{c}63.87^{* * *} \\
(1.27)\end{array}$ & $\begin{array}{c}3.64 \\
(12.39)\end{array}$ & $\begin{array}{c}2.87 \\
(12.88)\end{array}$ & $\begin{array}{c}43.68^{* * *} \\
(3.34)\end{array}$ & $\begin{array}{l}-14.62 \\
(19.36)\end{array}$ \\
\hline Age dummies & No & Yes & Yes & No & Yes & Yes & No & Yes \\
\hline $\mathrm{R}^{2}$ & 0.02 & 0.08 & 0.08 & 0.01 & 0.07 & 0.07 & 0.04 & 0.10 \\
\hline Number of observations & 1423 & 1371 & 1371 & 1423 & 1371 & 1371 & 1423 & 1371 \\
\hline
\end{tabular}

Notes. Dependent variable: SDG contribution to others. Robust standard errors in brackets. Significance levels: ${ }^{* * *}=1 \%,{ }^{* *}=5 \%,{ }^{*}=10 \%{ }^{\text {a }}$ Broad definition includes Economics (narrow), Business Administration, Public Policy, and Marketing and Management Communication. ${ }^{\mathrm{b}}$ Adjusted for narrow $/$ broad definition of Economics. ${ }^{\mathrm{c}}$ Trust question coded $1=$ Most people can be trusted, 0 = Don't know/Don't want to answer, -1 = You cannot be too careful. 


\subsection{Differences in Punishment Behavior}

Economists (broad definition in parentheses) punish slightly less often in the social dilemma game with punishment (SDGP) than students in the other disciplines: $31.8 \%$ (34.7\%) versus $36.1 \%$ $(36.3 \%)$. However, contrary to Hypothesis $\mathrm{H} 2$, we reject that the proportion of those who punish varies between economists and non-economists $\left(\chi^{2}=1.08, p=0.30\right.$ for the narrow and $\chi^{2}=0.42, p=0.52$ for the broad definition). Punishment is weakly correlated with contributions in the SDG $(\rho=0.05$, $p=0.04)$ but uncorrelated with giving in the DG $(\rho=0.04, p=0.18)$. These results continue to hold when adding controls in logistic regressions (see Table 3 ).

Economics has a negative but insignificant marginal effect on punishment both for the narrow and broad definitions. This does not change when adding covariates. Those who answer the control questions correctly are around 15 percentage points less likely to punish; but economics students were not more likely to answer correctly the control questions for the SDGP $\left(\chi^{2}=1.83, p=0.18\right)$. We hypothesized that punishment might be correlated with inequity aversion (as proxied by the amount given in the DG) and with the contribution in the SDG as well as the level of trust (specifications 2 and 4). Only the contribution in the SDG is significant, but it has a very small marginal effect: An individual who contributes the full endowment of 100 in the SDG, would be 9 percentage points more likely to punish than an individual who contributes zero in the SDG.

The final two specifications in Table 3 disaggregate the 'other disciplines' category and show that only political science students differ significantly from economics students in their punishment behavior. They are 12 percentage points more likely to punish than economists.

Comparing punishment in the two treatments that we ran for the SDGP, we find no significant difference in punishment frequencies (own group: $37.4 \%$, other group: $33.9 \%, \chi^{2}=2.00, p=0.16$ ). We also estimate the regressions in Table 3 separately for the own group and the other group treatments (Supplementary A, Tables A3 and A4). This does not change our finding that economists do not punish differently from students in other disciplines. The finding that political science students differ significantly from economics students in their punishment behavior, however, is driven by the own group treatment, whereas there is no significant difference in the other group treatment.

The pattern continues to hold when considering separately punishment behavior of 'contributor' types and 'free rider' types based on their contributions in the SDG. Among the 'contributors' ('free riders'), 36.8\% of economists (22.6\%) punish the free rider in the SDGP, compared to 38.2\% (22.9\%) among the other disciplines. Logistic regressions with controls added reveal no significant difference either in punishment patterns among economics students compared to other students, no matter whether we focus just on 'contributors' in the SDG (the marginal effect of being an economist is -4.0 percentage points, $p=0.44$ ) or on those who contributed zero in the SDG (the marginal effect is 7.4 percentage points, $p=0.36$ ). The results hold also with the broad definition of economics.

Result 2. There is no difference between economics students and other disciplines in the proportion of subjects who punish a free rider in the social dilemma game with punishment. This finding also holds when considering a broad definition of economics that includes students in other programs with a heavy focus on economics in the curriculum. 
Table 3. Logistic regressions for punishment behavior in the social dilemma game with punishment.

\begin{tabular}{|c|c|c|c|c|c|c|}
\hline Variable & (1) & (2) & (3) & (4) & (5) & (6) \\
\hline Economics (narrow) & $\begin{array}{l}-0.04 \\
(0.04)\end{array}$ & $\begin{array}{l}-0.04 \\
(0.04)\end{array}$ & & & $\begin{array}{l}\text { Reference } \\
\text { category }\end{array}$ & $\begin{array}{l}\text { Reference } \\
\text { category }\end{array}$ \\
\hline Economics (broad) ${ }^{a}$ & & & $\begin{array}{l}-0.02 \\
(0.03)\end{array}$ & $\begin{array}{l}-0.03 \\
(0.03)\end{array}$ & & \\
\hline Business Administration & & & & & $\begin{array}{c}0.05 \\
(0.05)\end{array}$ & $\begin{array}{c}0.04 \\
(0.05)\end{array}$ \\
\hline Public Policy & & & & & $\begin{array}{c}-0.17^{*} \\
(0.10)\end{array}$ & $\begin{array}{l}-0.16 \\
(0.11)\end{array}$ \\
\hline Marketing and Management Communication & & & & & $\begin{array}{c}0.03 \\
(0.07) \\
\end{array}$ & $\begin{array}{c}0.04 \\
(0.07) \\
\end{array}$ \\
\hline Other discipline & & Reference & ategory & & & \\
\hline Psychology & & & & & $\begin{array}{l}-0.01 \\
(0.05)\end{array}$ & $\begin{array}{c}0.04 \\
(0.06)\end{array}$ \\
\hline Law & & & & & $\begin{array}{c}0.05 \\
(0.05)\end{array}$ & $\begin{array}{c}0.03 \\
(0.05)\end{array}$ \\
\hline Political Science & & & & & $\begin{array}{l}0.12 * * \\
(0.05)\end{array}$ & $\begin{array}{l}0.12 * * \\
(0.05)\end{array}$ \\
\hline Medicine & & & & & $\begin{array}{l}-0.03 \\
(0.06)\end{array}$ & $\begin{array}{l}-0.01 \\
(0.06)\end{array}$ \\
\hline Other subject & & & & & $\begin{array}{c}0.08 \\
(0.08)\end{array}$ & $\begin{array}{c}0.13 \\
(0.08)\end{array}$ \\
\hline Male & & $\begin{array}{c}0.04 \\
(0.03)\end{array}$ & & $\begin{array}{l}0.05^{*} \\
(0.03)\end{array}$ & & $\begin{array}{c}0.03 \\
(0.03)\end{array}$ \\
\hline Knows the DG & & $\begin{array}{l}-0.04 \\
(0.03)\end{array}$ & & $\begin{array}{l}-0.04 \\
(0.03)\end{array}$ & & $\begin{array}{l}-0.05 \\
(0.03)\end{array}$ \\
\hline SDGP control questions correct & & $\begin{array}{c}-0.15 \\
* * * \\
(0.04)\end{array}$ & & $\begin{array}{c}-0.15 \\
* * * \\
(0.04)\end{array}$ & & $\begin{array}{c}-0.13^{* * *} \\
(0.04)\end{array}$ \\
\hline Trust $^{b}$ & & $\begin{array}{l}-0.02 \\
(0.02)\end{array}$ & & $\begin{array}{l}-0.02 \\
(0.02)\end{array}$ & & \\
\hline Semester & & $\begin{array}{c}0.01 \\
(0.01)\end{array}$ & & $\begin{array}{c}0.01 \\
(0.01)\end{array}$ & & $\begin{array}{c}0.01 \\
(0.01)\end{array}$ \\
\hline DG amount given & & $\begin{array}{l}0.0004 \\
(0.001)\end{array}$ & & $\begin{array}{l}0.0004 \\
(0.001)\end{array}$ & & \\
\hline SDG contribution & & $\begin{array}{c}0.0009 \\
* * \\
(0.0004) \\
\end{array}$ & & $\begin{array}{c}0.0009 \\
* * \\
(0.0004)\end{array}$ & & \\
\hline $\begin{array}{l}\text { Age dummies } \\
\text { Number of observations }\end{array}$ & $\begin{array}{l}\text { No } \\
1423\end{array}$ & $\begin{array}{c}\text { Yes } \\
1371\end{array}$ & $\begin{array}{l}\text { No } \\
1423\end{array}$ & $\begin{array}{c}\text { Yes } \\
1371\end{array}$ & $\begin{array}{l}\text { No } \\
1423\end{array}$ & $\begin{array}{c}\text { Yes } \\
1371\end{array}$ \\
\hline
\end{tabular}

Notes. Dichotomous dependent variable: Punishment. Marginal effects. Robust standard errors in brackets. Significance levels: ${ }^{* * *}=1 \%,{ }^{* *}=5 \%,{ }^{*}=10 \%$. ${ }^{\text {a }}$ Broad definition includes Economics (narrow), Business Administration, Public Policy, and Marketing and Management Communication. ${ }^{\mathrm{b}}$ Trust question coded $1=$ Most people can be trusted, 0 = Don't know/Don't want to answer, $-1=$ You cannot be too careful.

\section{Discussion}

In line with several previous studies, we found that compared to all other study areas, economists give less in the dictator game and contribute less in our social dilemma game. Nevertheless, we did not find that economists punish free riders less frequently compared to other disciplines.

Some factors related to the experimental design may have influenced how subjects behaved. Most notably, since the experiment was conducted in class, subjects were provided with less anonymity towards their peers than in a standard lab setting. The average dictator giving is $38.1 \%$ in our study, and this is substantially above the mean of $28 \%$ that Engel [34] finds in his meta-analysis. Yet, our results are comparable to those of e.g., Andreoni and Vesterlund [35] when considering the 
relevant subpopulations of our sample that are comparable to their sample. Specifically, they find that economists give $25 \%$ of their endowment compared to $26.9 \%$ in our study.

In our social dilemma game, subjects contributed with $60.1 \%$ on average. This is somewhat lower than e.g., the average contributions of 70\% that Thöni et al. [36] find among a representative sample of Danes in a one-shot linear public goods game without punishment, which entails a similar social dilemma as in our setting. However, the difference in contributions seems reasonable, considering that in Thöni et al.'s public goods game subjects got 0.5 DKK back for every 1 DKK they contributed $^{7}$, whereas subjects did not receive anything back from their own contributions in our social dilemma game.

In the social dilemma game with punishment, $35.6 \%$ of the subjects chose to punish the free rider. Few studies provide details on punishment frequencies in social dilemmas. However, the levels of punishment that we find are comparable to two studies that have analyzed in great detail punishment in public goods games: Anderson and Putterman [37] report a 37.2\% punishment rate of "low" contributors by "high" contributors and Carpenter [38] report numbers that imply a 50\% punishment rate by "contributor types" (p. 532).

While overall punishment behavior seems consistent with that found under real stakes, we cannot rule out that the nature of the stakes (real vs. hypothetical) interacts with the investigated effect of being an economist. Specifically, a potential alternative explanation for the lack of differences in punishment behavior could be that economists behave differently from non-economists only when real money is at stake. Exploring this is left for further research.

Both economic education and self-selection into economics have been found to be significant factors for students' behavior. In our study, we do not find that the economics-other discipline gap in giving changes with the number of semesters a student was enrolled. One reason for this could be that we collected data in the Spring term, which meant that all but five subjects in our study $(0.04 \%)$ were past their 1st semester. Consequently, economics students already had considerable training in economic reasoning. Several studies suggest a diminishing marginal effect of exposure to economic reasoning (see Section 1 ).

An alternative approach is to regress the outcomes on the number of economics courses that students have taken, which we can approximate from the standard curricula that students follow in the first two years, where there are no electives. Counting the number of courses in micro, macro, or financial economics up to the fourth semester (10 ECTS = a full course), law, medicine, and psychology have zero such courses, political science and marketing \& management communication have one such course, business administration has 3.5 courses, and economics and public policy have six courses. Regressions reveal that giving in the DG and SDG is decreasing in the number of economics courses (Supplementary A, Table A5). For punishment behavior, there is no significant effect of the number of economics courses.

One has to be careful, however, when interpreting these results. Ideally, we would separate the impact of the number of economics courses ('indoctrination') from the impact of being enrolled in a particular program ('self-selection') by looking at within-discipline variation in the number of economics courses that students had. However, in our setting we lack such variation because in most programs either all students have zero or all students have one economics course. That is, the number of economics courses accumulated captures both aspects because it often maps one-to-one to a degree program. Indeed, if one replaces the slope coefficient for the number of economics courses with dummies for each observed number of economics courses that a student accumulated, one sees that the contribution pattern is not monotonically decreasing in the number of economics courses taken.

Even though we find large differences between economists and other disciplines in contributions in the dictator and social dilemma games, it is striking that economics students do not differ from

7 In the experiment run by Thöni et al., contributions were doubled and then divided among the four members of the group. 
other students in the frequency with which they punish free riders. This holds irrespective of whether subjects punish free riding in their own group or in another group. Our study was powered to detect a minimum difference of 0.11 in the proportion of individuals who punish between economists and non-economists ( $\alpha=0.05$, power $=0.8$; see Supplementary $\mathrm{C}$ ). Thus, even if differences in punishment behavior do exist, they are relatively small.

Our findings suggest that punishment and contribution behavior in social dilemmas are distinct. This is in line with the view advanced by Fehr and Gächter [14] that punishment of free riders does not reflect a general predisposition to contribute but is triggered by a negative emotional reaction to free riding. Thus, one may speculate that emotional reactions are not as affected by economic reasoning than is the perhaps more deliberate decision to contribute.

Our finding that economics students are just as willing to sanction non-cooperative behavior as other students qualifies the debate on behavioral differences between economists and other disciplines. The literature has focused on games where prosocial behavior is manifested in giving to others or contributions to public goods. Here, economists often contribute less than others (also in our setting), which suggests that economic reasoning may harm (conditional) cooperation and lead to lower provision of public goods. However, real-life social dilemmas typically offer agents an opportunity to punish free riders. Once this aspect is considered, our findings lead to the less pessimistic view that the presence of economists may not alter cooperation in social dilemmas all that much, because economists are just as willing to punish free riders.

Finally, our study showed that psychology and medicine students exhibited distinct behaviors in the dictator and social dilemma games compared to the other examined study areas. This suggests that a focus on economists 'being different' may be too narrow and miss other 'exceptions'. Future research in this field should be careful to extend the range of disciplines considered and disaggregate them beyond the dichotomous categories 'economics' and 'other disciplines'. This will provide a more thorough understanding of the population validity and potential student bias in experimental economics and other behavioral sciences.

Supplementary Materials: Experimental instructions and appendices are available online at http:/ /www.mdpi. com/2073-4336/9/4/75/s1.

Author Contributions: The experiment was designed and conducted by J.P.K. and K.S.P. All authors contributed equally to the analysis and writing of the paper.

Funding: This project was supported by funding from the Interacting Minds Centre at Aarhus University, grant no 2017-143.

Acknowledgments: We are grateful for helpful comments on our experimental design by the members of TRIBE, led by Marco Piovesan, at Copenhagen University. We especially thank Jacob Ankjær Weinrich Rasmussen for feedback and discussions.

Conflicts of Interest: The authors declare no conflict of interest.

\section{References}

1. Samuelson, P.A. The Pure Theory of Public Expenditure. Rev. Econ. Stat. 1954, 36, 387-389. [CrossRef]

2. Fischbacher, U.; Gachter, S. Social Preferences, Beliefs, and the Dynamics of Free Riding in Public Goods Experiments. Am. Econ. Rev. 2010, 100, 541-556. [CrossRef]

3. Chaudhuri, A. Sustaining cooperation in laboratory public goods experiments: A selective survey of the literature. Exp. Econ. 2011, 14, 47-83. [CrossRef]

4. Marwell, G.; Ames, R.E. Economists free ride, does anyone else?: Experiments on the provision of public goods, IV. J. Public Econ. 1981, 15, 295-310. [CrossRef]

5. Ifcher, J.; Zarghamee, H. The rapid evolution of homo economicus: Brief exposure to neoclassical assumptions increases self-interested behavior. J. Behav. Exp. Econ. 2018, 75, 55-65. [CrossRef]

6. Carter, J.R.; Irons, M.D. Are Economists Different, and If So, Why? J. Econ. Perspect. 1991, 5, 171-177. [CrossRef] 
7. Frank, B.; Schulze, G.G. Does economics make citizens corrupt? J. Econ. Behav. Org. 2000, 43, 101-113. [CrossRef]

8. Frey, B.S.; Meier, S. Selfish and Indoctrinated Economists? Eur. J. Law Econ. 2005, 19, 165-171. [CrossRef]

9. Bauman, Y.; Rose, E. Selection or indoctrination: Why do economics students donate less than the rest? J. Econ. Behav. Org. 2011, 79, 318-327. [CrossRef]

10. Frank, R.H.; Gilovich, T.; Regan, D.T. Does Studying Economics Inhibit Cooperation? J. Econ. Perspect. 1993, 7, 159-171. [CrossRef]

11. Blais, A.; Young, R. Why do people vote? An experiment in rationality. Public Choice 1999, 99, 39-55. [CrossRef]

12. Wang, L.; Malhotra, D.; Murnighan, J.K. Economics Education and Greed. Acad. Manag. Learn. Educ. 2011, 10, 643-660. [CrossRef]

13. Falk, A.; Fehr, E.; Fischbacher, U. Driving Forces behind Informal Sanctions. Econometrica 2005, 73, $2017-2030$. [CrossRef]

14. Fehr, E.; Gächter, S. Altruistic punishment in humans. Nature 2002, 415, 137-140. [CrossRef] [PubMed]

15. Yamagishi, T. The provision of a sanctioning system as a public good. J. Pers. Soc. Psychol. 1986, 51, 110-116. [CrossRef]

16. Dong, Y.; Zhang, B.; Tao, Y. The dynamics of human behavior in the public goods game with institutional incentives. Sci. Rep. 2016, 6, 28809. [CrossRef] [PubMed]

17. Eckel, C.C.; Grossman, P.J.; Johnston, R.M. An experimental test of the crowding out hypothesis. J. Public Econ. 2005, 89, 1543-1560. [CrossRef]

18. Cadsby, C.B.; Maynes, E. Choosing between a socially efficient and free-riding equilibrium: Nurses versus economics and business students. J. Econ. Behav. Org. 1998, 37, 183-192. [CrossRef]

19. Zelmer, J. Linear Public Goods Experiments: A Meta-Analysis. Exp. Econ. 2003, 6, 299-310. [CrossRef]

20. Kagel, J.H.; Kim, C.; Moser, D. Fairness in Ultimatum Games with Asymmetric Information and Asymmetric Payoffs. Games Econ. Behav. 1996, 13, 100-110. [CrossRef]

21. Yezer, A.M.; Goldfarb, R.S.; Poppen, P.J. Does Studying Economics Discourage Cooperation? Watch What we do, not what we say or How we Play. J. Econ. Perspect. 1996, 10, 177-186. [CrossRef]

22. Engelmann, D.; Strobel, M. Preferences over Income Distributions: Experimental Evidence. Public Financ. Rev. 2007, 35, 285-310. [CrossRef]

23. Macro, D.; Weesie, J. Inequalities between Others Do Matter: Evidence from Multiplayer Dictator Games. Games 2016, 7, 11. [CrossRef]

24. Nowak, M.A.; Sigmund, K. Evolution of indirect reciprocity by image scoring. Nature 1998, 393, 573-577. [CrossRef] [PubMed]

25. Filippin, A.; Raimondi, M. The Patron Game: The Individual Provision of a Public Good. Games 2018, 9, 35. [CrossRef]

26. Fehr, E.; Gächter, S. Cooperation and Punishment in Public Goods Experiments. Am. Econ. Rev. 2000, 90, 980-994. [CrossRef]

27. Selten, R. Die Strategiemethode zur Erforschung des eingeschränkt rationalen Verhaltens im Rahmen eines Oliogopolexperimentes. In Beiträge zur experimentellen Wirtschaftsforschung; Sauerman, H., Ed.; J.C.B. Mohr: Tübingen, Germany, 1967; pp. 136-168.

28. Hertwig, R.; Ortmann, A. Experimental practices in economics: A methodological challenge for psychologists? Behav. Brain Sci. 2001, 24, 383-451. [PubMed]

29. Gillis, M.T.; Hettler, P.L. Hypothetical and Real Incentives in the Ultimatum Game and Andreoni's Public Goods Game: An Experimental Study. East. Econ. J. 2007, 33, 491-510. [CrossRef]

30. Kocher, M.G.; Martinsson, P.; Visser, M. Does stake size matter for cooperation and punishment? Econ. Lett. 2008, 99, 508-511. [CrossRef]

31. Camerer, C.F.; Hogarth, R.M. The Effects of Financial Incentives in Experiments: A Review and Capital-Labor-Production Framework. J. Risk Uncertain. 1999, 19, 7-42. [CrossRef]

32. Rubinstein, A. A Sceptic's Comment on the Study of Economics. Econ. J. 2006, 116, C1-C9. [CrossRef]

33. Miller, D.T. The norm of self-interest. Am. Psychol. 1999, 54, 1053-1060. [CrossRef] [PubMed]

34. Engel, C. Dictator games: A meta study. Exp. Econ. 2011, 14, 583-610. [CrossRef]

35. Andreoni, J.; Vesterlund, L. Which is the Fair Sex? Gender Differences in Altruism. Q. J. Econ. 2001, 116, 293-312. [CrossRef] 
36. Thöni, C.; Tyran, J.-R.; Wengström, E. Microfoundations of social capital. J. Public Econ. 2012, 96, 635-643. [CrossRef]

37. Anderson, C.M.; Putterman, L. Do non-strategic sanctions obey the law of demand? The demand for punishment in the voluntary contribution mechanism. Games Econ. Behav. 2006, 54, 1-24. [CrossRef]

38. Carpenter, J.P. The demand for punishment. J. Econ. Behav. Org. 2007, 62, 522-542. [CrossRef]

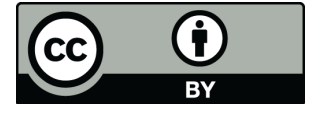

(c) 2018 by the authors. Licensee MDPI, Basel, Switzerland. This article is an open access article distributed under the terms and conditions of the Creative Commons Attribution (CC BY) license (http://creativecommons.org/licenses/by/4.0/). 